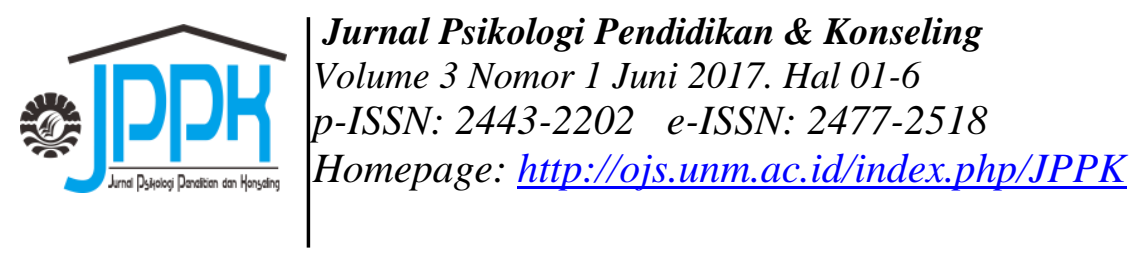

\title{
Pengujian konsep psikoterapi unconditional positive regard pada mahasiswa perempuan
}

\author{
Beatriks Novianti Kiling-Bunga \\ Psikologi Perkembangan, Universitas Nusa Cendana \\ Email: boenga.eve@gmail.com \\ Indra Yohanes Kiling \\ Psikologi Komunitas, Peneliti Institute of Resource Governance and Social Change \\ Email: iykiling@gmail.com
}

(Diterima: 02-April-2016; di revisi: 10-Juni-2016; disetujui: 28-Juni-2016)

\begin{abstract}
One of the psychotheraphy approaches that has given positive contributions to the psychiatry is Carl Rogers Client-Centered approach. One of three main conditions that Rogers emphasizes in the approach is Unconditional positive regard. The main condition is called as the curative factor of client-centered theraphy. The article is discussing the study process of unconditional positive regard concept in a person which the sample is the female students. Questions and process flow scheme are also discussed in this article. The study concept is regarded to be able to contribute knowedge to the counseling practitioners in case of facing the student's problem.
\end{abstract}

Keywords: Client-centered therapy; unconditional positive regard; process scheme concept

\begin{abstract}
Abstrak. Salah satu pendekatan psikoterapi yang telah memberikan kontribusi positif di ilmu kesehatan jiwa adalah pendekatan client-centered dari Carl Rogers. Salah satu dari tiga kondisi inti yang ditekankan Rogers dalam pendekatannya adalah unconditional positive regard. Kondisi inti ini disebut sebagai faktor kuratif dari terapi client-centered. Paper ini membahas pengujian proses terjadinya konsep unconditional positive regard dalam diri orang coba yang adalah mahasiswa perempuan. Pertanyaan serta alur skema proses turut dibahas dalam paper ini. Hasil pengujian konsep ini diharap mampu memberikan pengetahuan kepada praktisi konseling terutama ketika berhadapan dengan mahasiswa.
\end{abstract}

Kata kunci: client-centered therapy; unconditional positive regard; skema proses konsep

Copyright (9 2016 Universitas Negeri Makassar. This is an open access article under the CC BYNC-ND license (http://creativecommons.org/licenses/by-nc-nd/4.0/).

\section{PENDAHULUAN}

Psikologi Kesehatan sampai saat ini mengenal banyak jenis psikoterapi, namun salah satu pendekatan yang telah memberikan dampak luas di dalam dunia konseling adalah personcentered atau client-centered (terpusat pada klien) yang dikembangkan oleh Carl Rogers (Crisp, 2010). Rogers mengemukakan bahwa dengan menghadirkan kondisi-kondisi inti dalam sebuah relasi maka klien akan dapat memperoleh perubahan positif dalam terapi yang diukur dengan meningkatnya unconditional positive self regard dari individu (Patterson \& Joseph, 2006), kondisi inti ini harus bersamaan dengan hadirnya kontak psikologis antara konselor dan klien tanpa adanya kondisi dan syarat dari konselor (Cochran, 2009). Kondisi inti yakni kongruensi, empati, dan unconditional positive regard (UPR) adalah tiga prinsip dasar dari pendekatan terapi 
client-centered yang merupakan hasil reduksi dari enam prinsip awal yang dikemukakan Rogers (Gatongi, 2007).

UPR adalah penerimaan dan pemahaman atas pengalaman dan emosi klien tanpa adanya kondisi ataupun ekspektasi (Snodgrass, 2007). Rogers menekankan bahwa hanya lewat penerimaan terhadap klien maka klien dapat melakukan kontak dan menyadari penyangkalan (denial) serta distorsi internal dalam dirinya. Meskipun beberapa peneliti menyatakan bahwa empati atau kongruensi merupakan kondisi inti yang paling penting dalam seorang terapis, Wilkins (Sparrow, 2008) menyatakan bahwa UPR adalah faktor kuratif (penyembuh) dalam teori client-centered, dan tetap dapat memberikan efek yang positif meski ditengah absennya kongruensi dan empati. UPR dan selfcentered theory memiliki dampak yang sangat luas dalam kehidupan dan dapat ditemukan dalam pengalaman sehari-hari dari individu. Rogers menjelaskan bahwa kondisi inti untuk terapi person-centered bisa diterapkan dalam dunia pekerjaan, pendidikan, maupun psikososial (Crisp, 2010), khususnya dalam pendidikan, sepertimentoring terhadap siswa bermasalah, konsep UPR menjadi inti utama dari proses mentoring (Jones, 2009), atau pada Behavior Intervention Support Team (BIST), program intervensi pada sekolah-sekolah yang menekankan pada hubungan yang didasari UPR dari orang tua siswa kepada siswa (Boulden, 2010). dan berdasar hasil penelitian terbukti bahwa terapi client-centered merupakan terapi yang efektif, bahkan lebih efektif dari routine care oleh general practitioners (Patterson \& Joseph, 2006). Bahkan UPR dan teori clientcentered telah menjadi dasar pemikiran dari Psikologi Pastoral khususnya dalam growth counseling yang dikemukakan pertama kali oleh Howard Clinebell (Snodgrass, 2007).

Konseling dengan pendekatan terpusat pada klien berpotensi untuk mampu memberikan solusi kepada mahasiswa dalam menyelesaikan masalah yang dihadapinya. Salah satu masalah yang sering dihadapi mahasiswa adalah rasa cemas yang terkait dengan karir yang akan ditempuh pasca menyelesaikan studi. Rasa cemas ini jika tidak diselesaikan akan dapat berpengaruh pada prestasi studi (Kiling \& Bunga, 2014). Kajian tersebut memperlihatkan bahwa konseling memiliki manfaat untuk mahasiswa atau individu dewasa awal, asalkan dilakukan dengan sistematis dan mahasiswa sendiri berminat untuk menggunakan layanan konseling. Berdasarkan pengamatan penulis pada beberapa universitas seperti Universitas Kristen Satya Wacana, Universitas Nusa Cendana dan The University of Adelaide, Australia, layanan konseling kepada mahasiswa sampai saat ini masih mengalami tantangan karena mahasiswa cenderung kurang berminat untuk menggunakan layanan tersebut.

Selain keuntungan untuk menangani permasalahan kecemasan mahasiswa, konseling yang memanfaatkan konsep UPR juga bisa mempersiapkan para pemuda dan mahasiswa dalam menyongsong Masyarakat Ekonomi ASEAN (MEA). Layanan konseling yang baik dan mudah diakses akan memberdayakan kapasitas masyarakat terutama di daerah terpencil untuk membuat mereka lebih siap dalam menghadapi persaingan dalam dunia kerja di era MEA (Bunga \& Kiling, 2015). Analisa tersebut memperlihatkan bahwa penggunaan konseling kepada mahasiswa memiliki banyak fungsi yang relevan dengan keadaan masyarakat Indonesia yang termutakhir.

Data-data empirik di atas membuat penulis tertarik untuk mengetahui lebih jauh skema terjadinya UPR di dalam individu yang tidak memiliki permasalahan dan beban psikologis yang berat. Mengetahui proses terbentuknya sebuah konsep di dalam individu akan mempermudah praktisi konseling dalam memahami klien sehingga nantinya praktisi akan mampu menyesuaikan dengan keadaan individu atau klien. Peneliti psikologi juga dapat memperoleh keuntungan dari penelusuran terbentuknya konsep UPR yang dapat dijadikan sebagai acuan dalam melakukan pengkajian lebih lanjut pada konsep dan konteks yang terkait. Penggalian serta penerapan yang konsisten dan mendalam pada konseling dan UPR diharapkan bisa memberikan keuntungan-keuntungan kepada mahasiswa seperti yang telah dibahas di atas.

\section{METODE}

Di dalam paper ini, individu yang akan dilihat skema UPR pribadinya disebut orang coba (OC). Proses penggalian skema UPR yang akan dijalani oleh OC ada 2 tahap, yakni pertama asesmen data awal dengan interviu untuk menanyakan komitmen, pengenalan awal terhadap konsep UPR, dan data singkat 
mengenai kehidupan individu. Tahap kedua meliputi wawancara tertutup untuk mencari tahu terbentuknya skema UPR di dalam kehidupan OC. Pertanyaan yang digunakan adalah pertanyaan tertutup sehingga memudahkan pemantauan skema proses. Pertanyaan disusun oleh penulis dengan mempertimbangkan beberapa poin penting yang disebutkan di bawah. Data awal dari OC satu dan OC dua akan dibahas di bawah.

$\begin{array}{ll}\text { Asesmen Awal Orang } & \text { Coba } \\ \text { Orang coba satu: } & \\ \text { Nama Inisial } & : \text { VAS } \\ \text { Jenis Kelamin } & \text { : Perempuan } \\ \text { Agama } & : \text { Kristen Protestan } \\ \text { Usia } & : 18 \text { tahun } \\ \text { Pendidikan terakhir } & : \text { SMA } \\ \text { Etnis } & \text { : Batak, Tionghoa, Jawa }\end{array}$

Ketika ditanyakan tentang komitmen orang coba, VAS mengatakan bahwa dia menyanggupi untuk mengikuti seluruh proses dalam penggalian skema UPR ini.

Ketika dikenalkan dengan skema UPR, VAS tidak terkejut dan kesulitan untuk memahami karena VAS sendiri adalah seorang mahasiswi Fakultas Psikologi.

VAS memiliki pemahaman bahwa UPR adalah penerimaan konselor terhadap klien tanpa syarat.

VAS adalah anak ketiga dari tiga bersaudara. VAS memiliki satu kakak perempuan dan satu kakak laki-laki. VAS lahir dan besar di kota Palembang, Sumatera Selatan serta mengenyam pendidikan hingga SMA di kota tersebut. Dari orang tua, ayah dan ibu VAS bekerja walaupun ayah VAS sempat di-PHK sehingga kondisi keharmonisan keluarga sempat goyah. VAS tumbuh dengan perhatian dan kasih sayang yang cukup sehingga menjadi individu yang aktif, dan prososial sehingga mudah bergaul dalam lingkungannya. VAS memiliki kepribadian yang cukup ekstrovert sehingga cepat beradaptasi. VAS merupakan mahasiswa yang memiliki potensi tinggi, sehingga pada tahun pertamanya sudah menjadi juara 1 Psychodebate yang diadakan Fakultas Psikologi UKSW. VAS juga merupakan anggota dari Senat Mahasiswa Fakultas Psikologi UKSW dengan posisi sebagai magang bidang Profesional Skill. Dalam kehidupan spiritual, VAS merupakan majelis jemaat di Gereja Methodist Indonesia yang terletak di Salatiga. VAS merupakan individu yang aktif dalam kegiatan kerohanian.
Di dalam aktivitas fisik, VAS rajin jogging setidaknya 2 kali seminggu.

Orang coba dua:

$\begin{array}{ll}\text { Nama Inisial } & : \text { MN } \\ \text { Jenis Kelamin } & \text { : Perempuan } \\ \text { Agama } & : \text { Kristen Protestan } \\ \text { Usia } & : 20 \text { tahun } \\ \text { Pendidikan terakhir } & \text { : SMA } \\ \text { Etnis } & \text { : Jawa }\end{array}$

MN menyanggupi mengikuti kegiatan penggalian skema UPR dengan syarat tidak berbenturan dengan kegiatan perkuliahan.

MN sudah mengenal konsep UPR terlebih dahulu dari perkuliahan konseling dan psikoterapi yang diikutinya di dalam studi S1nya.

MN memiliki pemahaman bahwa UPR adalah pemberian penghargaan dari penghargaan untuk menimbulkan sikap positif dari konseli.

MN adalah anak keempat dari lima bersaudara. MN memiliki dua kakak perempuan, satu kakak laki-laki dan satu adik laki-laki. MN lahir dan besar di kota Salatiga, Jawa Tengah dan menempuh pendidikan hingga jenjang perguruan tinggi di kota tersebut. Dari orang tua, hanya ayah MN yang bekerja untuk menafkahi keluarga, sehingga ibu MN memiliki waktu penuh untuk membesarkan dan memberi perhatian pada kelima anaknya. MN tumbuh dengan kekangan dan larangan bergaul yang cukup ketat sehingga $\mathrm{MN}$ menjadi individu yang sulit bergaul dalam lingkungannya dan cenderung hanya tinggal di rumahnya saja ketika waktu senggang. MNsering mendapat tuntutan lebih dalam hal akademis dengan tekanan ekstra bahwa kakak-kakaknya memiliki nilai-nilai yang tinggi dan MN diharuskan untuk sama bahkan melebihi prestasi dari kakak-kakaknya. MN sendiri memiliki prestasi akademis yang baik dan saat ini sedang menjabat sebagai ketua umum Senat Mahasiswa Fakultas Psikologi UKSW. MN baru aktif dalam kegiatan ekstrakurikuler ketika menempuh perguruan tinggi. Dalam kehidupan spiritual, MNmemiliki rutinitas beribadah tiap hari Minggu tanpa kegiatan spiritual ekstra lainnya. MN mengakui bahwa di dalam kehidupan spiritual sendiri, dia belum cukup konsisten dalam menerapkan ajaran agamanya dalam kehidupan sehari-hari. Di dalam aktivitas fisik, MNtidak memiliki olahraga tetap dan rutin sehingga dia cenderung jarang beraktivitas fisik. 
UPR adalah penerimaan dan pemahaman atas pengalaman dan emosi individu tanpa adanya kondisi ataupun ekspektasi. Definisi ini akan dipakai dalam penelusuran skema proses sehingga penting bagi OC untuk memahami dengan benar definisi ini. Sebelum penelusuran skema proses, OC telah ditanyai pendapatnya terkait definisi UPR dan kemudian diberitahukan definisi yang disusun penulis. OC kemudian dipastikan telah menerima dan memahami definisi operasional yang disebutkan di atas.

Poin penting dalam penyusunan skema proses: Beberapa poin penting yang terkait dengan UPR serta penyusunan skema proses adalah (1) UPR terdapat dalam dunia pendidikan, pekerjaan, dan psikososial, (2) Berdasarkan asesmen, pendidikan akan dikaitkan dengan interaksi OC dan dosen, (3) Pekerjaan akan dikaitkan dengan interaksi dalam senat mahasiswa, dan psikososial akan dikaitkan dengan interaksi OC dengan anggota keluarga., (4) penerimaan, (5) pemahaman, (6) emosi, (7) pengalaman, (8) tanpa syarat, kondisi, situasi, ekspektasi terlebih dahulu.

Penerimaan, pemahaman, emosi, pengalaman serta tanpa adanya syarat terlebih dahulu merupakan kata-kata kunci yang membentuk konsep UPR secara utuh. Penekanan terhadap kata-kata ini dibutuhkan untuk memastikan skema yang digali adalah UPR sebenar-benarnya dan bukan konsep lain yang menyerempet maknanya.

Pertanyaan dalam Skema Proses: (1) Pernahkah anda menerima orang lain tanpa syarat? ( $\rightarrow$ Q2; T $\rightarrow$ Q3; cek penerimaan), (2) Dapatkah anda memahami orang lain tanpa berada dalam kondisi tertentu? (Y $\rightarrow$ Q4; $\mathrm{T} \rightarrow \mathrm{Q} 5$; cek pemahaman), (3) Apakah anda selalu menyertakan syarat untuk bisa menerima orang lain? (Y $\rightarrow$ EXIT; $\mathrm{T} \rightarrow \mathrm{Q} 2$; konfirmasi penerimaan), (4) Dalam berorganisasi, bisakah anda mendengarkan pengalaman rekan anda tanpa keinginan untuk didengarkan terlebih dahulu? ( $\mathrm{Y} \rightarrow \mathrm{Q} 6 ; \mathrm{T} \rightarrow \mathrm{Q} 7$; cek pengalaman dalam organisasi), (5) Apakah untuk memahami orang lain anda memiliki situasi dan kondisi yang harus dipenuhi terlebih dahulu? (Y $\rightarrow$ EXIT; $T \rightarrow$ Q4; konfirmasi pemahaman), (6) Dapatkah anda memahami dan merespon emosi dari anggota keluarga anda dengan tepat dan tanpa harapan tertentu? (Y $\rightarrow \mathrm{Q} 8 ; \mathrm{T} \rightarrow \mathrm{Q} 9$; cek emosi dalam hubungan psikososial), (7) Dalam Senat, pikiran anda harus didengarkan terlebih dahulu.
(Y $\rightarrow$ EXIT; $\mathrm{T} \rightarrow \mathrm{Q6} ;$ konfirmasi pengalaman organisasi), (8) Anda merasa telah bisa memahami cara mengajar dosen tanpa harus dipahami cara belajar anda oleh dosen. (Y $\rightarrow$ UPR OK; T $\rightarrow$ Q10; cek pemahaman dalam pendidikan), (9) Anda berharap untuk bisa dipahami emosinya sebelum memahami emosi slh seorang anggota keluarga anda. (Y $\rightarrow$ EXIT; $\mathrm{T} \rightarrow \mathrm{Q} 8$ ), (10) Yang terpenting adalah dosen mengerti cara belajar anda terlebih dahulu daripada anda memahami cara mengajar dosen tersebut. ( $\mathrm{Y} \rightarrow$ EXIT; T $\rightarrow$ UPR OK; konfirmasi pemahaman dalam dunia pendidikan).

EXIT di sini maksudnya adalah tidak ada pertanyaan lagi yang akan diajukan dan proses telah selesai. Jika belum sampai pada EXIT atau UPR OK, maka pertanyaan akan terus dilanjutkan sesuai dengan skema yang telah diatur. Pertanyaan yang ada telah disusun sedemikian rupa untuk memastikan konsep UPR secara utuh dapat dilihat pada diri OC. Penyusunan dilakukan dengan memperhatikan secara detil definisi operasional serta poin-poin penting yang telah disebutkan sebelumnya.

Alur hasil coba skema proses kepada Orang Coba Satu:

$\mathrm{Y} \rightarrow$ 2. $\mathrm{Y} \rightarrow$ 4. $\mathrm{Y} \rightarrow$ 6. T $\rightarrow$ 9. $\mathrm{Y}=$ EXIT.

Alur hasil coba skema proses kepada Orang Coba Dua:

$\mathrm{Y} \rightarrow$ 2. $\mathrm{T} \rightarrow$ 5. $\mathrm{T} \rightarrow 4$. $\mathrm{Y} \rightarrow$ 6. $\mathrm{T} \rightarrow$ 9. $\mathrm{Y}=$ EXIT.

\section{HASIL DAN PEMBAHASAN}

Orang coba pertama menjawab (ya) pada pertanyaan pertama yang bermaksud untuk melihat penerimaan tanpa syarat pada kehidupan orang coba, hal ini terus diafirmasi dengan kehadiran konsep UPR dalam kehidupan berorganisasi OC seiring jawaban (ya) pada pertanyaan keempat. Konsep UPR akhirnya gugur di dalam kehidupan psikososial OC yang dilihat dari kemampuan merespon emosi dari anggota keluarga tanpa adanya ekspektasi terlebih dahulu.

Orang coba kedua memiliki alur yang hampir sama dengan orang coba pertama dimana konsep UPR gugur dalam kehidupan psikososial OC yang dilihat dari kemampuan merespon emosi dari anggota keluarga tanpa adanya ekspektasi. Hal yang membedakan adalah jawaban (tidak) pada pertanyaan kedua yang setelah dikonfirmasi di pertanyaan kelima menunjukkan bahwa OC mampu untuk 
memahami orang lain tanpa situasi dan kondisi yang harus dipenuhi terlebih dahulu.

Dikaitkan dengan pada hasil asesmen awal, baik OC satu dan OC dua memiliki kualitas hubungan di dalam keluarga yang begitu kompleks dengan latar belakang pola asuh dan interaksi dalam anggota keluarga yang menyebabkan OC satu dan OC dua memiliki ekspektasi terlebih dahulu untuk bisa merespon ungkapan emosi dari anggota keluarganya dengan baik. Hal ini membawa ke kesimpulan bahwa UPR adalah sebuah konsep yang dipengaruhi oleh kualitas interaksi dengan lingkungan terdekat individu, sebagai contoh keluarga, dan bahwa UPR akan berbeda penerapannya ketika diperhadapkan dalam lingkungan yang berbeda, misal perilaku UPR akan berbeda ketika dalam lingkungan pekerjaan, pendidikan, maupun dalam lingkungan sosial.

Hal ini sesuai dengan apa yang disebutkan oleh Jones (2009) bahwa konsep UPR dari individu terhadap orang yang tidak dikenalnya dengan baik akan dipengaruhi oleh pengalaman dan pola interaksi individu dengan orang yang telah dikenalnya dengan baik atau lingkungan terdekatnya. Prinsip juga berlaku ketika menerapkan konseling kelompok seperti yang dijelaskan oleh Cox dan Espinoza (2005). Bentuk interaksi intra- dan inter-kelompok akan mempengaruhi pembentukan UPR di dalam kelompok tersebut. Praktisi konseling perlu memperhatikan hubungan klien dengan keluarganya untuk mengetahui secara baik kualitas hubungan klien dengan keluarga yang berpengaruh kepada kualitas UPR atau proses pembentukan UPR yang dimiliki oleh klien tersebut. Hubungan yang berkualitas dan positif dengan keluarga akan mempermudah individu dalam membangun konsep UPR pada orang yang baru dikenal. Begitu pula sebaliknya, hubungan yang kurang berkualitas dengan anggota keluarga bisa menghambat proses pembentukan UPR dalam proses konseling.

Hal yang menarik dalam kajian ini adalah bahwa bentuk interaksi tersebut muncul pada mahasiswa perempuan. Menurut penjelasan Rojewski (1994), kelompok pemuda perempuan sedang berada dalam tahap transisi dari pemahaman diri menuju ke tahap eksplorasi diri. Hal ini mungkin mempengaruhi kemampuan pemuda perempuan dalam memberikan penghargaan terhadap dirinya maupun terhadap diri orang lain yang lebih berbasis kepada pengalaman subjektif dengan orang terdekat dibanding pertimbangan objektif berdasarkan faktor-faktor yang relevan. Faktor relevan yang dimaksud adalah seperti niat dan tujuan dari orang lain dan pemahaman situasi yang tengah berlangsung. Praktisi konseling perlu menyiasati ini ketika berhadapan dengan mahasiswa perempuan dengan memperhatikan latar belakang individu tersebut sehingga mampu memahami pola pemahaman dari klien yang terbangun dari pengalaman subjektif tersebut. Dengan mengerti pola ini, praktisi konseling akan lebih mudah untuk menyesuaikan dan mempermudah dalam menjalin rapport serta dalam proses konseling.

Temuan-temuan tersebut penting untuk diingat dalam penerapan proses konseling, mentoring atau program intervensi lain yang berbasis pada klien. Memahami latar belakang klien lebih lanjut sangat penting dalam proses penumbuhan UPR. Memahami orang terdekat serta bentuk interaksi dari klien akan membantu identifikasi proses pembentukan UPR yang akan menunjang kelancaran proses konseling atau mentoring.

\section{SIMPULAN DAN SARAN}

UPR penting untuk diterapkan dalam lingkungan sosial seseorang sedini mungkin ketika masih anak. Kelompok-kelompok maupun forum-forum anak yang tersebar di banyak daerah bisa menjadi target penerapan konsep UPR, sehingga pemenuhan hak anak bisa tercapai dan pembangunan kesehatan mental yang berdasarkan perilaku positif bisa dimulai sejak dini (Kiling, 2013). Kemampuan untuk berpikir dan berperilaku positif dari kecil akan mempengaruhi pertumbuhan dan performa individu ketika dewasa. Proses konseling dan mentoring selanjutnya perlu memperhatikan preferensi dan kecenderungan klien atau mentee dalam menaruh ekspektasi pada lingkungannya. Ekspektasi tersebut akan mempengaruhi pembangunan UPR di dalam dirinya. Simpulan ini dapat dimanfaatkan peneliti dan terapis di bidang psikoterapi dan psikologi kesehatan, khususnya pendekatan client-centered untuk mempertimbangkan latar belakang kualitas interaksi klien sebelum melakukan penelitian atau terapi. Kajian lebih lanjut terhadap proses konseling yang berpusat pada klien pada mahasiswa dibutuhkan agar data empirik yang 
dihasilkan mampu memperkuat temuan dari penelusuran skema proses dalam paper ini.

\section{DAFTAR RUJUKAN}

Boulden, W. T. (2010). The Behavior Intervention Support Team (BIST) Program: Underlying Theories. Reclaiming Children and Youth. 19(1), 17-21.

Bunga, B. N., \& Kiling, I. Y. (2015). Konseling karir dalam menyongsong MEA di Nusa Tenggara Timur. In Surya, M. (Ed.), Proceedings of The International Seminar and Workshop on Guidance and Counseling. Yogyakarta: Prodi Bimbingan dan Konseling Universitas PGRI Yogyakarta.

Cochran, J. L. et al. (2009). Growing Play Theraphy Up: Extending Child-Centered Play Therapy to Highly Aggressive Teenage Boys. Person-Centered and Experiential Psychotherapies. 9(4), 290301.

Cox, R. S., \& Espinoza, A. (2005). CareerCommunity Development: A Framework for Career Counseling and Capacity Building in Rural Communities. Journal of Employment Counseling, 42(4), 146-158.

Crisp, R. (2010). A Person-Centred Perspective to Counselling in Educational and Vocational Agencies. Australian Journal of Guidance \& Counseling. 20(1), 22-30.

Gatongi, F. (2007). Person-centred approach in schools: Is it the answer to disruptive behaviour in our classrooms? Counseling Psychology Quarterly. 20(2), 205-211.

Jones, K., Doveston, M., \& Rose, R. (2009). The Motivations of Mentors: Promoting Relationships, Supporting Pupils, Engaging with Communities. Pastoral Care in Education. 27,1, 41-51.

Kiling, I. Y. (2013). Forum Anak Sumba Timur sebagai wadah pemenuhan hak partisipasi anak. Opini. Waingapu: www.waingapu.com

Kiling, I. Y., \& Bunga, B. N. (2014). Konseling karir dan pemahaman diri sebagai potensi solusi untuk kecemasan gagal mahasiswa. Jurnal Transformasi Edukasi, 3(1), 60-64.
Patterson T. G., \& Joseph, S. (2006). Development of a self-report measure of unconditional positive self-regard. Psychology and Psychotherapy: Theory, Research and Practice. 79, 557-570.

Rojewski, J. W. (1994). Career Indecision Types for Rural Adolescents From Disadvantaged and Nondiadvantaged Backgrounds. Journal of Counseling Psychology, 41(3), 356-363.

Snodgrass, J. (2007). From Rogers to Clinebell: Exploring the History of Pastoral Psychology. Pastoral Psychology. 54, 513-525.

Sparrow, G. S. (2008). Informed love as a curative factor. Mental Health, Religion \& Culture. 11(6), 567-577. 